\title{
New Cultivar Documentation Needs to be Upgraded
}

\author{
Paul R. Fantz ${ }^{1}$ \\ Department of Horticultural Science, North Carolina State University, Raleigh, NC 27695-7609
}

Last summer the ASHS Publications Committee informed me that my name had been placed in nomination as an Associate Editor for the category "Breeding, Cultivars, Rootstocks, and Germplasm Resources: Vegetables and Ornamentals." I was nominated because of experience in this area. Previously, I was involved in the Carla azalea (Rhododendron L.) breeding program at North Carolina State Univ. This program lead to the release of several selections whose descriptions were published in HortScience (e.g., Benson et al., 1990). I have assisted and continue to assist state nursery operators in documenting new germplasm through international registrars affiliated with professional societies (e.g., Sulgrove, 1991), through the process of obtaining plant patents (e.g., Hefner, 1994), and through publication in HortScience (e.g., Bilderback et al., 1990). I informed the committee representative that I would adhere to the International Code of Nomenclature for Cultivated Plants and that the section on Cultivar \& Germplasm Releases in HortScience needed to be strengthened in documentation (especially for ornamentals), particularly in its weakest area-description of the germplasm/ cultivar.

In Aug. 1994, I attended and presented a paper at The Second International Symposium on Nomenclature of Cultivated Plants (Tukey, 1995) held at the Urban Horticultural Center, Univ. of Washington, Seattle. Documentation of new germplasm was a topic of discussion in several small groups that included international registrars, lawyers, and those developing or selecting new germplasm (primarily ornamentals). Comments on new cultivar documentation in HortScience generally were unfavorable and included words and phrases such as "inadequate," "substandard," "inferior to registration requirements," and "of poor quality to be nearly worthless." Our image is tarnished in this area and must be improved with more rigorous standards in germplasm/ cultivar documentation.

The ASHS Publications Manual [American Society for Horticultural Science (ASHS), 1991] provides guidelines for the "Cultivar and Germplasm Releases" section. The ASHS

Received for publication 16 Apr. 1996. Accepted for publication 16 May 1996. Viewpoints are published in HortScience to provide members of the American Society for Horticultural Science an opportunity to share their experiences and comments on matters of concern to horticulturists. These are not statements of official Society policy, nor do they necessarily reflect the views of a majority of the Society's members. The cost of publishing this paper was defrayed in part by the payment of page charges. Under postal regulations, this paper therefore must be hereby marked advertisement solely to indicate this fact.

${ }^{1}$ Professor.
Publications Committee has adopted additions to the guidelines: 1) The description must provide evidence of superiority of the new release over currently grown standard cultivars (controls) for traits of interest unless rigorous testing is not appropriate or necessary for a particular release (e.g., novel traits in unadapted germplasm or crops with long life cycles); 2) pedigree information should be included; 3) the experimental designation used during cultivar testing should be noted; 4) names of cultivars similar to the new release should be noted; and 5) data may be objective or subjective, but convincing to peers reviewing the manuscript and to the Science Editor of HortScience. The ASHS Publications Committee should be commended for revising the guidelines. I agree with the revisions being proposed, except for the guideline that allows descriptive data to be subjective. The description section is the weakest area and should adhere to more scientific rigorous standards. As they appear now, descriptions are inferior to registration requirements.

In my opinion, ASHS should expand on the guidelines provided to authors and include more substance regarding structure and content for papers published on new germplasm/ cultivar releases, as Chapter 2 does for typical research articles published in HortScience (ASHS, 1991). Four general issues are involved: 1) Should one use the term "variety" or "cultivar" in the publication? 2) Is the author releasing germplasm or a cultivar? 3) Various plant crops (agronomic, fruits, ornamentals, vegetables) are treated as a broad general unit. Should these crops require similar or different criteria for the evidence presented in the "Description" section? 4) What content should be a minimal requirement in documenting new cultivars?

\section{VARIETY VS. CULTIVAR}

The international rules adopted for naming plants regard the terms "variety" and "cultivar" as differing plant taxa, not synonymous terms, and are punctuated differently for easy recognition. The international term "variety" is a subspecific rank (Articles 4 and 24; Greuter, 1994) designated for populations sufficiently distinct to warrant some taxonomic notice but not well enough set off to be called a species (Cronquist, 1988). They are recognized by distinct morphological features selected by environmental processes through the process of sexual reproduction. Japanese boxwood [Buxus microphylla Siebold \& Zucc. var. japonica (Müll. Arg.) Rehd. \& E.H. Wils.] is an example of members of a varietal population being brought into cultivation. A variety is distinguished by adding the abbreviation "var." to the binomial of the species followed by an epithet in lowercase and underlined or italicized.
The international term "cultivar" denotes an assemblage of cultivated plants that is distinguished clearly by any characters (morphological, physiological, cytological, chemical, or others), that is uniform and stable in its characteristics, and that, when reproduced (sexually or asexually), retains its distinguishing characters (Article 10; Brickell, 1980). Buxus microphylla var. japonica 'Richardii' is an example of a cultivar of Japanese boxwood selected for its dark green foliage, cold hardiness, and large growth habit in the landscape. A cultivar name is recognized by its enclosure in single quotes, capitalization of every word, and a lack of italics or underlining.

Recognition of variety and cultivar as nonsynonymous terms on an international scale is contrary to the understanding of some in the industry and the ASHS community who regard these terms as interchangeable. I recommend that ASHS publications adhere to the international rules for plant names.

\section{GERMPLASM VS. CULTIVAR}

Germplasm and cultivars are separate entities to some individuals. Cultivars include material selected for desirable trait(s) that would be marketed by the industry. Germplasm includes material that contains germ cells and their precursors, which serve as the bearers of heredity and are fundamentally independent of other cells. Germplasm generally would be released as breeding stock for a desirable genetic trait and would be designated by abbreviations, numerals, or arbitrary sequences of letters, not names. However, the international rules (Brickell, 1980) included germplasmunder "cultivar" and recommended (Article $31 \mathrm{R} 31 \mathrm{~A})$ strongly that names be used, "except as established custom in a country or for a crop requires (e.g. sugar cane [Saccharum officinarum L.] POJ2878)."

\section{PLANT CATEGORIES}

Types of crops that can be released are variable; thus, documentation will vary depending on the crop involved. I recognize two distinct groups. Category 1 involves those crops selected for physiological, chemical, cytological, or other genetic traits in which they appear to be similar and possibly indistinguishable morphologically from other cultivars. This category includes agronomic crops, fruits, vegetables, and some ornamentals. New cultivars of these crops arise through breeding programs that involve hybridization and rigorous testing. Breeders often may have to meet minimum requirements set for the plant group by an association. Evidence commonly would be the experimental designation of the testing involved, with a summation of results. Descriptive data for these plants would include 
evidence of superiority or higher yields over current standard cultivars.

Category 2 includes those plants selected for one or more unique or novel morphological traits, e.g., most ornamentals. These plants often do not undergo rigorous testing, but are released after a short time when sufficient propagules are available. Morphological traits are visual and easily measurable. Evidence for these plants should be quantitative descriptions of key morphological features plus comparisons with known cultivars expressing similar traits. Characters of segregation should be described for the reader to identify known cultivars with traits similar to the new release.

\section{THE CULTIVAR PAPER}

Documentation of new cultivars is important for archival purposes. ASHS should require basic information on new cultivars that includes derivation of the name; uniqueness; origin; a quantitative description; segregation from similar cultivars; cultural information, including propagation, vouchering, or registration; and availability. Listed below are the component parts of such a cultivar paper with data that I believe should be included in each section.

\section{Introduction}

The introduction should be a concise paragraph introducing the reader to the new plant material. It should include two integral parts: a justification of why the material is being released and a clear statement of those traits for which it was selected, i.e., those that are unique, novel, different, or superior to other cultivar selections currently available.

\section{Origin}

This section should include a paragraph on the history of the cultivar leading to its selection and release. Present a pedigree, either in words or as a figure, for Category 1 plants. List all prior names or designations used for the cultivar during the testing period, as well as information leading to selection of the name used. For example, Liriope muscari (Decne.) L.H. Bailey 'Gilner White' was displayed at the North Carolina State Univ. Arboretum for several years. The arboretum distributed divisions under the name 'Gilner White' to some nurseries. However, the plant was released as 'Traebert White.' Both names occur in the trade today.

\section{Description}

The first paragraph should include quantitative data; criteria differ for Category 1 and Category 2 plants, as noted above. Manuscripts describing plants in Category 2 should include one or more photographs (growth habit and close-up) illustrating unique or novel morphological trait(s). The second paragraph should present a qualitative description, in- cluding observations or other information of interest and importance to the reader. The third paragraph should include an inventory of currently available standard cultivars that are similar to the new cultivar, and provide comparisons between them and the newly released selection. For ornamentals in particular, characters of segregation need to be documented. How does one identify the new cultivar from existing cultivars?

Many ornamental cultivars are selected based on foliage, flower, or fruit color. Perceptions of color can have many interpretations, depending on the observer. Colors of plant materials can change depending on plant location, season of the year, age of an organ, juvenility vs. adult stages, or environmental variables (e.g., sun vs. shade). Color needs to be quantified. Recently, two out-of-print sources (Royal Horticultural Society, 1995; Wilde and Voigt, 1995) have reissued color charts. Instrumental measurement provides a readily replicated description of color and avoids the effects of differences in color perception among human observers (Voss, 1992). Therefore, electronic color determination in the CIELAB system (McLaren, 1976), when feasible, would be desirable (e.g., Tourjee et al., 1993).

\section{Culture}

Information presented here should assist those who will be growing the new cultivars. Recommendations should be made by those who released the plant and know it well. Information on propagation also is essential to cultivars of Category 2 plants. Growers will receive propagules as stock material and need current propagating information to increase their inventory for marketing.

\section{Availability}

Information should indicate vouchering of the plant for archival purposes. This ensures preservation of the germplasm for others to examine. Herbarium specimens may be prepared for Category 2 plants and deposited at the herbarium of the originating institution(s) or at the Herbarium of the U.S. National Arboretum. In lieu of a herbarium specimen, a living specimen may be deposited at a specified botanic garden or with an international registrar who usually requires living material. Plants in Category 1 commonly are vouchered with a designated agency, such as the American Seed Trade Association. Additional information should indicate the availability of propagules of the cultivar.

\section{CONCLUSION}

Documentation of new cultivars is very important. Current ASHS guidelines need to be strengthened to include the minimal information needed for archival purposes and to be equivalent to registration. Guidelines for authors should be expanded to include the sub- headings outlined above: an introduction with justification for release and a statement on the uniqueness of the cultivar; an origin that documents the history of the new selection, all names or designations used during testing, and selection of the name used for release; a quantitative description of the cultivar (recognizing that criteria are different for a Category 1 and a Category 2 plant), useful observational information, and a comparison with known similar or standard cultivars; a cultural section with information on propagating and growing the cultivar; an availability section with vouchering information and information on obtaining propagules of the cultivar; and a bibliography of literature cited. The paper should follow established international rules of nomenclature.

As an Associate Editor, I intend to request that authors revise their papers based on the recommendations of reviewers and myself to meet the standards as addressed herein. Following these guidelines will strengthen the documentation and standardize the format of published cultivar release articles.

\section{Literature Cited}

American Society for Horticultural Science. 1991. ASHS publications manual. Amer. Soc. Hort. Sci., Alexandria, Va.

Benson, D.M., P.R. Fantz, and W.A. Skroch. 1990. 'Fred Cochran' carla azalea. HortScience 25:490-491.

Bilderback, T.E., D.G. Cagle, and P.R. Fantz. 1990. 'Greenthumb Peppermint' azalea. HortScience 25:236-237.

Brickell, C.D. (ed.). 1980. International code of nomenclature for cultivated plants-1980. Regnum Veg. 104:1-32.

Cronquist, A. 1988. The evolution and classification of flowering plants. 2nd ed. New York Botanical Garden, New York.

Greuter, W. (ed.). 1994. International code of botanical nomenclature. Regnum Veg. 131:1-389.

Hefner, R.B. 1994. Ilex x 'Hefcup'. U.S. Patent 8537. U.S. Plant Trademark Office, Washington, D.C.

McLaren, K. 1976. The development of the CIE $1976(\mathrm{~L} * \mathrm{a} * \mathrm{~b} *)$ uniform colour space and colourdifference formula. J. Soc. Dyers \& Colourists 92:338-341.

Royal Horticultural Society. 1995. The Royal Horticultural Society's colour chart. 3rd ed. Royal Hort. Soc., London.

Sulgrove, S.M. (registrar). 1991. 'Treetop' English ivy. Amer. Ivy Soc. registration 910292; AIS 91-055. Dayton, Ohio.

Tourjee, K.R., J. Harding, and T.G. Bryne. 1993. Colorimetric analysis of Gerbera flowers. HortScience 28:735-737.

Tukey, Jr., H.B. (ed.). 1995. Proceedings of the second international symposium on the taxonomy of cultivated plants. Acta Hort. Proc. vol. 413. Intl. Soc. Hort. Sci., Leiden, The Netherlands.

Voss, D.H. 1992. Relating colorimeter measurement of plant color to the Royal Horticultural Society Colour Chart. HortScience 27:12561260.

Wilde, S.A. and G.K. Voigt. 1995. Munsell color charts for plant tissues. 3rd ed. Munsell Color, Macbeth Div. of Kollmorgen Instruments Corp., New Windsor, New York. 